\title{
Special Issue of the Geneva Papers
}

During the last year, a growing number of unsolicited manuscripts have been submitted for publication in The Geneva Papers on Risk and Insurance. An Editorial Board has been constituted to evaluate these manuscripts and select those that are considered worth publishing in a "Special Issue" of the Geneva Papers.

The members of this ad hoc Editorial Board are : Carla ANGELA (Rome), Karl BORCH (Bergen), Robert CARTER (Nottingham), Louis EECKHOUDT (Mons), Elmar HELTEN (Mannheim), Eugenio PRIETO (Madrid), and Jean-Jacques ROSA (Paris).

Authors wishing to submit a paper for this Special Issue are requested to send 5 copies of their manuscript to the Editors of the Geneva Papers. They are also invited to take into account the following recommendations.

1. The preference of the Editorial Board will go to papers offering an empirical support to proposed theories rather than dealing with pure theory.

2. The manuscript should start with a clear statement of the problem to be treated and an indication of the main published results related to this problem.

3. It should end up with a clear, verbal statement of the findings, their significance, their limitations, and their possible applications.

4. In the course of the text, a great attention should be devoted to a careful explanation of the mathematical methods used, of their relevance for the problem under discussion, and to the verbal presentation of the empirical results appearing in equations, tables and graphs.

5. The tables and figures should be presented on separate sheets.

6. The footnotes should appear at the foot of the pages. They should not be used to indicate references but to complete the text by remarks that are not directly relevant to the general discussion.

7. The references should be ordered in alphabetical order at the end of the text, and be quoted in the text by indicating either the rank of the reference in the list or its year of publication, e.g. :

either : "... the idea originated with Arrow [2], and Debreu [6, chapter 7]..."

or : “... the idea originated with Arrow [1953], and Debreu [1959, chapter 7]..."

In the first case, the references should be set up according to the following pattern :

2. ARROW, K. J. : “Le rôle des valeurs boursières pour la répartition la meilleure des risques", Econométrie, 1953, 41-47; English translation Arrow [3] reprinted in Arrow [4, chapter 4].

6. DEBREU, G. : Theory of Value, Wiley, New York, 1959. 
In the second case :

ARROW, K. J. [1953] : “Le rôle des valeurs boursières pour la répartition la meilleure des risques", Econométrie, Vol. XI, 41-47; English translation [1963] reprinted in Arrow [1970, chapter 4].

DEBREU, G. [1959] : Theory of Value, Wiley, New York.

8. The author should prepare an abstract of his paper, limited to about 100 words.

The Editors. 